\title{
A Novel External Esophageal Perfusion Model for Reflux-Associated Respiratory Symptoms
}

\author{
Qinzi Lia, ${ }^{a}$ Lingfei Konga Shuna Zhang ${ }^{a}$ Zhaoshuang Zhong ${ }^{a} \quad$ Xiaofeng Liu $^{\mathrm{a}}$ \\ Jinou Wang ${ }^{\text {b Jian Kang }}{ }^{\text {a }}$ \\ a Institute of Respiratory Diseases, First Affiliated Hospital, and becond Affiliated Hospital, China Medical \\ University, and ${ }^{\mathrm{C}}$ Department of Respiratory Diseases, Liaoning Electric Central Hospital, Shenyang, China
}

\section{Key Words}

Esophageal perfusion model, animals $\cdot$ Gastroesophageal

reflux $\cdot$ Guinea pig model of reflux disease $\cdot$ Perfusion

model $\cdot$ Reflux esophagitis

\begin{abstract}
Background and Objective: Gastroesophageal reflux disease (GERD) has been linked to a number of extra-esophageal symptoms and disorders, primarily in the respiratory tract. Current animal models of reflux esophagitis are adapted to diseases of the digestive system, rather than to refluxassociated respiratory symptoms. The aim of this study was to evaluate a novel external esophageal perfusion model to induce esophageal, tracheal and pneumonic histological injury similar to that associated with GERD. Methods: Twenty guinea pigs were randomized to the acid-treated or PBStreated group. Esophageal catheters were used to perfuse the esophageal lumen of guinea pigs with hydrochloric acid containing $1 \mathrm{~g} / \mathrm{l}$ pepsin or PBS for 14 days. The total cell number and cell differential counts in bronchoalveolar lavage fluid (BALF) were determined $24 \mathrm{~h}$ after the last perfusion. Histological changes in the esophageal, tracheal and pneumonic tissues were observed by hematoxylin-eosin staining. Results: The numbers of lymphocytes, eosinophils and total inflammatory cells in the BALF were significantly higher in
\end{abstract}

acid-perfused than PBS-perfused animals. Histological evidence suggested esophageal and pneumonic inflammations were prominent in acid-treated animals. Conclusion: Repetitive, acid-perfused, esophageal events copied the animal models of reflux esophagitis, and elicited inflammatory responses in the airways and lungs of guinea pigs.

Copyright $\odot 2010$ S. Karger AG, Basel

\section{Introduction}

Gastroesophageal reflux disease (GERD) develops when the reflux of stomach contents into the esophagus causes chronic, troublesome symptoms or complications [1]. Recognizable symptoms of GERD include heartburn and acid regurgitation, but the reflux of noxious material may have wider-reaching effects. In addition to the wellestablished esophageal complications associated with the disease [2], GERD is believed to lead to extra-esophageal symptoms and complications, primarily in the respiratory tract [3].

Few studies have investigated the mechanisms by which gastroesophageal reflux may cause respiratory diseases. At present, most of the publications have focused on the clinical field [4] and a few on changes in microvascular leakage in the airways induced by a single treatment

\section{KARGER}

Fax +4161306 1234 E-Mail karger@karger.ch www.karger.com

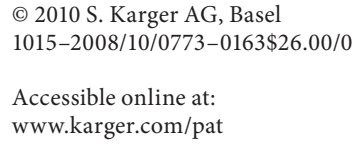


Table 1. Histological damage score used to assess inflammatory changes in the esophagus of guinea pigs

\begin{tabular}{lllr}
\hline Score & Epithelial damage & $\begin{array}{l}\text { Submucosal } \\
\text { edema }\end{array}$ & $\begin{array}{l}\text { Submucosal in- } \\
\text { flammatory cells }\end{array}$ \\
\hline 0 & normal & normal & 0 to $<5 / \mathrm{HPF}$ \\
1 & $\begin{array}{l}\text { mild surface lifting } \\
\text { intraepithelial separation } \\
\text { and surface lifting } \\
\text { epithelial cell loss to basal } \\
\text { cell layer or deeper }\end{array}$ & $\begin{array}{l}\text { moderate diffuse } \\
\text { edema }\end{array}$ & $\begin{array}{r}5 \text { to }<10 / \mathrm{HPF} \\
\text { severe edema }\end{array}$ \\
3 & & $\geq 15 / \mathrm{HPF}$ \\
& &
\end{tabular}

of the esophagus with hydrochloric acid $(\mathrm{HCl})[5,6]$. However, the development of clinical GERD is the result of repetitive esophageal stimulation by stomach contents, so it is unlikely that the pathophysiology of GERD can be accurately reproduced by a single esophageal treatment with $\mathrm{HCl}$. In order to probe the mechanisms underlying reflux-associated respiratory symptoms, appropriate animal models are required.

At present, animal models of esophageal reflux are primarily adapted to diseases of the digestive system, rather than reflux-associated respiratory symptoms. The aim of this study was to evaluate a novel, external esophageal, repetitive $\mathrm{HCl}$ perfusion model in guinea pigs for the purpose of improving the study of reflux-associated respiratory symptoms. This treatment paradigm resulted in bronchial inflammation.

\section{Animals and Methods}

All animal experimental design and manipulation procedures were approved by the Ethical Committee for Animal Use and Care of the Institute of Education of China Medical University. The guinea pigs were housed in 12-hour-light/12-hour-dark cycles with free access to food and water.

\section{Animals and Reagents}

Specific pathogen-free albino guinea pigs, weighing 350$450 \mathrm{~g}$, of both sexes were provided by the Laboratory Animal Center, College of Basic Medicine, China Medical University. Acetylcholine chloride, hydrochloric acid, chloramines and pentobarbital were obtained from Sigma (St. Louis, Mo., USA). Ketamine was purchased from Gutian Pharmaceuticals (Fujian, China). Pepsin was obtained from Sinopharm Chemical Reagents (Shanghai, China).

\section{Animal Grouping and Model Establishment}

Animals were housed in the animal unit for at least $72 \mathrm{~h}$ before experimentation. Twenty guinea pigs were randomized to two groups. In the experimental group $(\mathrm{n}=10)$, the esophagus was challenged with a solution of $\mathrm{HCl}$ containing $1 \mathrm{~g} / \mathrm{l}$ pepsin ( $\mathrm{HCl}-\mathrm{P}$ ) ( $\mathrm{pH} 1.0) ; \mathrm{HCl}$ was used in a $0.1-\mathrm{M}$ solution, and pepsin was added to simulate the gastric contents during the digestive process, based on the study by Adams et al. [7], at the same concentration found in the human stomach. In the control group, PBS ( $\mathrm{pH} 7.0)$ was used to treat the esophagus $(n=10)$. On the day of experimentation, guinea pigs were maintained under ketamine anesthesia (50 mg/kg i.p.) with additional injections given as necessary. Animals were placed in supine position, and a 5 -french catheter was inserted via the mouth into the lumen of the middle and lower esophagus. The esophagus of each animal was perfused with $\mathrm{HCl}$ $\mathrm{P}$ or PBS for $20 \mathrm{~min} /$ day for 14 days at a flow rate of $0.3 \mathrm{ml} / \mathrm{min}$ using a peristaltic pump. During perfusion, all animals were in a $30^{\circ}$ anti-Trendelenburg position.

\section{Bronchoalveolar Lavage and Cell Count}

Animals were sacrificed by cardiac puncture. After flushing the pulmonary vascular bed with sterile saline containing $1 \%$ heparin, the lung was flushed $6 \times$ with $5 \mathrm{ml}$ sterile saline for bronchoalveolar lavage fluid (BALF) recovery. The collected BALF was filtered with sterile gauze and centrifuged at $1,200 \mathrm{rpm}$ at $4^{\circ} \mathrm{C}$ for $10 \mathrm{~min}$ using a Universal 32R refrigerated centrifuge (Hettich, Tuttlingen, Germany); cell pellets were rinsed $3 \times$ with sterile saline and centrifuged at $1,200 \mathrm{rpm}$ at $4^{\circ} \mathrm{C}$ for $5 \mathrm{~min}$. A small fraction of the cells was suspended in normal saline at a density of $1 \times 10^{4} / 1$, and $50 \mu l$ of the cell suspension were loaded on a slide and centrifuged for subsequent hematoxylin-eosin (HE) staining to determine the prevalence of inflammatory cells. The remaining cells were resuspended in RPMI 1640 supplemented with $10 \%$ calf serum. The total BALF cell number was counted using a Neubauer chamber.

\section{Esophageal, Tracheal and Lung Tissue Pathology}

Following sacrifice, full-thickness sections of 1-cm esophagus from $0.5 \mathrm{~cm}$ above the gastroesophageal junction, the trachea and the right lung of the guinea pigs were lavaged with PBS and embedded in OCT. Tissues were stored at $-80^{\circ} \mathrm{C}$ until sectioned for histopathology. Tissues were cryosectioned at $8-\mu \mathrm{m}$ thickness and stained with HE for examination under a light microscope (Olympus BX51; Olympus, Tokyo, Japan). Slides of two sections from the esophagus of each animal were coded and subsequently scored for mucosal injury by a blinded observer using a previously reported, standardized damage score, which graded the degree of epithelial injury, submucosal edema and inflammatory infiltrates [8] (table 1).

Histopathological assessment of the trachea and lung tissue was performed blind on randomized sections. Inflammatory changes were graded using a semiquantitative scale of $0-5$ for perivascular eosinophilia, bronchiolar eosinophilia, epithelial damage and edema [9] (table 2). 
Table 2. Histopathological (HP) scoring system used to assess inflammatory changes in the lungs of guinea pigs

\begin{tabular}{|c|c|c|c|}
\hline HP grade & Perivascular and -bronchiolar eosinophilia & Edema & Epithelial damage \\
\hline 0 & normal & normal & normal \\
\hline 1 & low-grade cell influx, no tissue pathology & low-grade diffuse edema & low-grade cell loss \\
\hline 2 & $\begin{array}{l}\text { low/moderate cell influx } \\
\text { low-grade tissue damage }\end{array}$ & $\begin{array}{l}\text { moderate alveolar and } \\
\text { bronchiolar edema }\end{array}$ & low-grade cell loss \\
\hline 3 & moderate cell influx, low-grade tissue damage & regional and focal edema & moderate cell loss \\
\hline 4 & $\begin{array}{l}\text { moderate/high cell influx } \\
\text { marked tissue damage }\end{array}$ & pronounced edema & moderate cell loss \\
\hline 5 & $\begin{array}{l}\text { high-grade cell influx } \\
\text { significant tissue pathology }\end{array}$ & pneumonic-type edema & $\begin{array}{l}\text { epithelial metaplasia mu- } \\
\text { cous cell hyperplasia }\end{array}$ \\
\hline
\end{tabular}

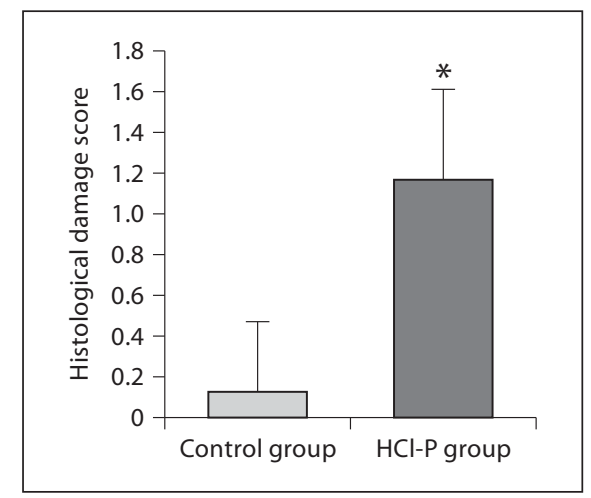

Fig. 1. Mucosal injury damage score in the distal esophageal tissue of perfused guinea pigs. Means \pm SD. ${ }^{*} \mathrm{p}<0.001$ vs. the PBStreated control group.

\section{Statistical Analysis}

Data were presented as medians, because inflammatory changes in the tracheal and lung tissue assessed by histopathological examination were graded using a semiquantitative scale.

Data were analyzed with SPSS 13.0 software. The results were expressed as means \pm SD. Differences between groups were analyzed by $t$ test and two-way analysis of variance (ANOVA) followed by Fisher's least significant difference test. A p value $<0.05$ was considered statistically significant.

\section{Results}

\section{Morbidity and Mortality}

All 20 guinea pigs survived the perfusion. However, there may have been some effect on food intake in the initial 3-5 days since acid-perfused animals lost $37 \mathrm{~g}$ during this period compared with $3 \mathrm{~g}$ in the control group $(\mathrm{p}<0.05)$. One week later, animals in the HCl-P-treated group resumed their usual diet and their weights stabilized. There were no deaths in either group.

A Viable Model for Gastroesophageal Reflux Disease

\section{Pathological Changes in the Esophagus, Trachea and} Lung Tissue

Mucosal injury damage scores in the distal esophageal tissue of guinea pigs are shown in figure 1. Compared to the PBS control group, the mucosal injury damage score in the HCl-P-perfused animals was markedly increased, $0.125 \pm 0.335$ in controls versus $1.175 \pm 0.385$ in animals treated with HCl-P ( $p<0.01$; fig. 1). Pathological changes in the esophagus were not observed in the PBS control animals (fig. 2a). In the esophagus of HCl-P-perfused animals, however (fig. 2b), we noted mild infiltration of inflammatory cells in the submucosa, basal and spinal cell hyperproliferation, papillar hypertrophy, epithelial hyperkeratinization, squamous cell expansion, and increases in the number of fibrin cells. These results were consistent with the typical histological findings associated with low-grade reflux esophagitis.

Guinea pigs in the PBS control group presented with normal tracheal structures, as the mucosal lining of the trachea exhibited no obvious swelling, and the tracheal walls remained smooth in these animals (fig. 3a). The HCl-P-treated group evidenced hyperplasia and duplicate-layer array of the ciliated columnar epithelium. In addition, we noted blood vessel congestion, as well as gland hyperplasia and goblet cell metaplasia. Airway epithelial desquamation was also evident in the HCl-P-perfused animals (fig. 3b).

In the PBS control animals, we found low numbers of inflammatory cells stained for $\mathrm{HE}$ in the distal airway walls, and the lung parenchyma was clear, lacy and essentially devoid of inflammatory cells (fig. 4a, c). Histopathologically, pulmonary inflammation was absent in the distal airway walls and lung tissue of PBS control animals (table 3). In contrast, in guinea pigs exposed to HCl-P, there were increased numbers of inflammatory cells, primarily eosinophils, in the lumen and wall of the distal airways

Pathobiology 2010;77:163-168 

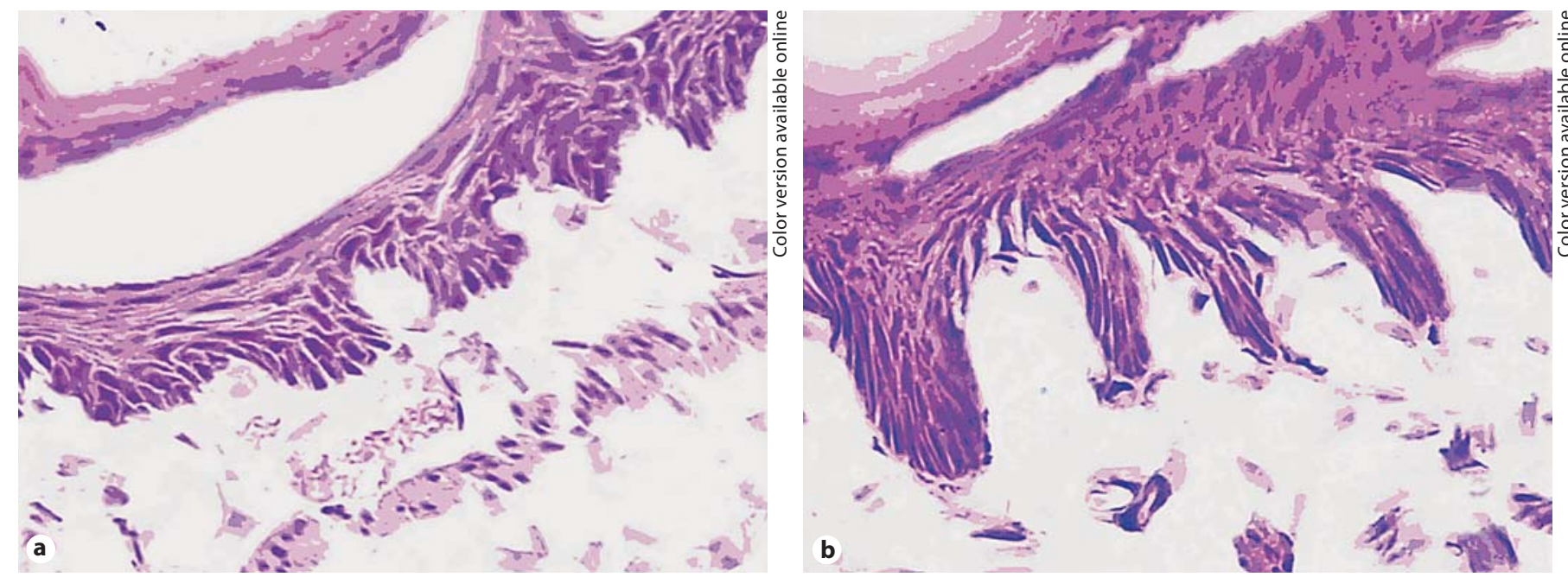

Fig. 2. Microscopic observation of the pathological changes in the distal esophagus of PBS-perfused (a) and $\mathrm{HCl}$-P-perfused guinea pigs (b). Obvious basal cell hyperproliferation, papillal hypertrophy and epithelial hyperkeratinization can be seen in the esophagus of the HCl-P model group. HE. $\times 400$.
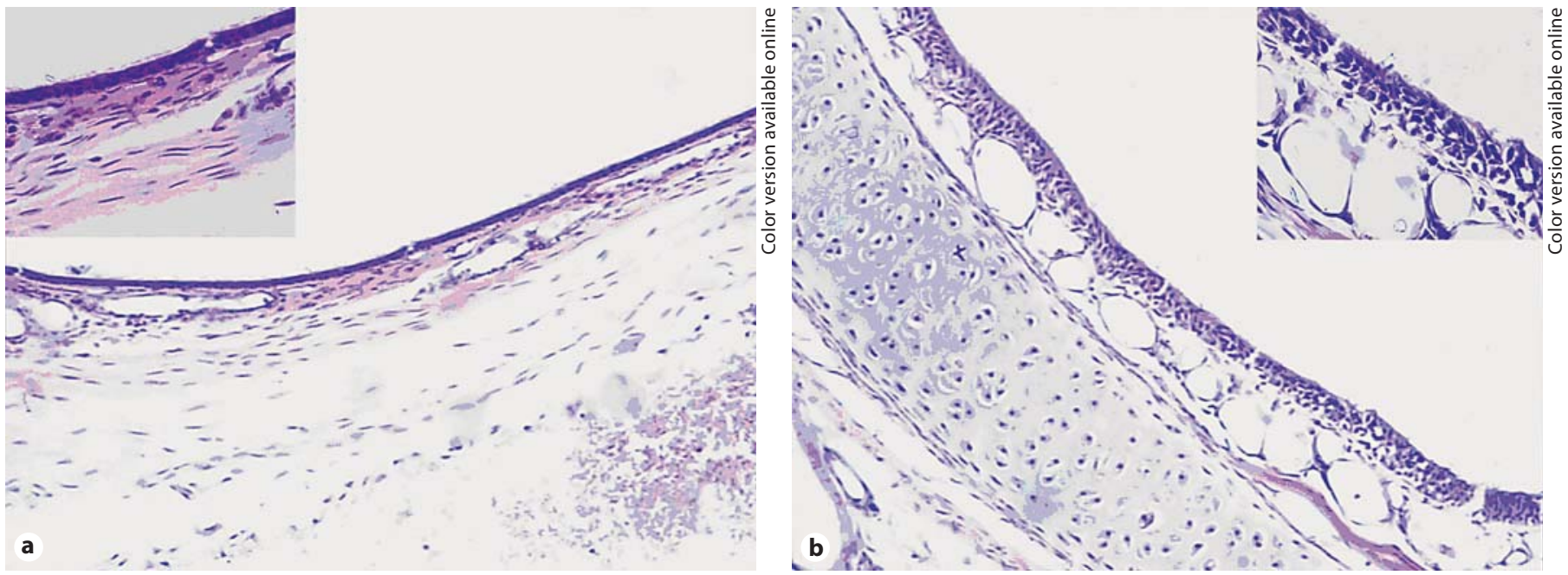

Fig. 3. Microscopic observation of the pathological changes in the trachea of guinea pigs of the PBS control group (a) and the HCl-P model group (b). The mucosal lining of the trachea exhibited obvious swelling in the HCL-P model group. HE. $\times 100$, inset: $\times 400$.

Table 3. Inflammatory changes in lung sections of the two groups

\begin{tabular}{llll}
\hline Groups & $\begin{array}{l}\text { Perivascular and -bron- } \\
\text { chiolar eosinophilia }\end{array}$ & Edema & $\begin{array}{l}\text { Epithelial } \\
\text { damage }\end{array}$ \\
\hline Control & $1(0-1)$ & $1(0-1)$ & $0(0-0)$ \\
HCl-P & $4(3-5)$ & $4(3-4)$ & $3(2-4)$ \\
\hline
\end{tabular}

(fig. 4b, d). The presence of eosinophils in the bronchiolar area showed anatomical correlation with tissue edema, epithelial cell hypertrophy and cell damage (table 3).

\section{Cell Numbers and Types Observed in Guinea Pig $B A L F$}

The total cell number, and lymphocyte and eosinophil counts were significantly increased in the BALF of HCl-P animals compared with the controls ( $\mathrm{p}<0.01$; table 4$)$. 

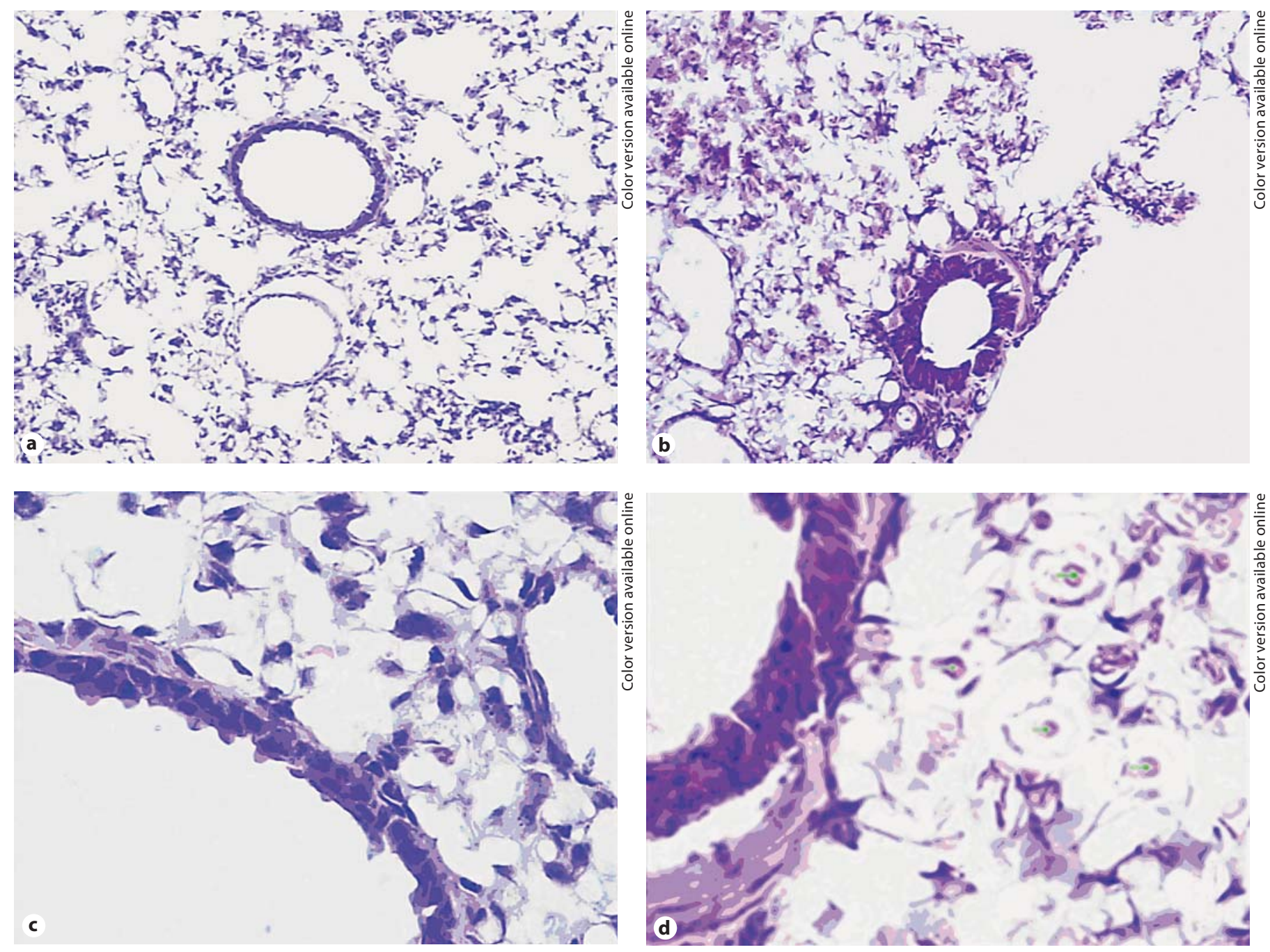

Fig. 4. Microscopic observation of the pathological changes in the distal airway wall and lung tissue of guinea pigs of the PBS control group (a, $\mathbf{c}$ ) and the HCl-P model group (b, d). In the HCl-P model group, obvious bronchiolar stenosis can be seen, and inflammatory cell infiltration, primarily eosinophils (arrows), is evident in the bronchiolar and lung tissue. a, b HE. $\times 100$. c, d HE. $\times 400$.

\section{Discussion}

The relationship between GERD and asthma has been extensively studied in recent years [4]. The average prevalence of reflux symptoms in adults with asthma was 59\%, suggesting a possible severity-response relationship between GERD and asthma. Until recently, due to the effects of antireflux therapy on asthma, it was not commonly known that GERD could interfere with airway reactivity and aggravate, or even induce, asthma.

At present, the animal models of GERD are mostly adapted to digestive system diseases such as reflux esoph-
Table 4. Total cell number and percentages of neutrophils, monocytes, lymphocytes and eosinophils in BALF

\begin{tabular}{lrr}
\hline Cell counts & $\begin{array}{l}\text { Control } \\
\text { group }\end{array}$ & $\begin{array}{l}\text { HCl-P } \\
\text { group }\end{array}$ \\
\hline Total cell number, $\times 10^{7}$ & $31.26 \pm 3.89$ & $105.67 \pm 6.78^{*}$ \\
Monocytes, \% & $83.7 \pm 1.54$ & $70.9 \pm 2.84$ \\
Neutrophils, \% & $5.6 \pm 1.96$ & $7.6 \pm 1.44$ \\
Lymphocytes, \% & $1.2 \pm 0.39$ & $4.8 \pm 1.26^{*}$ \\
Eosinophils, \% & $9.5 \pm 0.87$ & $16.69 \pm 0.92^{*}$ \\
\hline
\end{tabular}

${ }^{*} \mathrm{p}<0.01$ vs. the control group. $\mathrm{n}=10$; t test. 
agitis and Berrett's esophagus. These animal models have mostly been established via surgery, i.e. esophagoduodenal or esophagogastroduodenal anastomosis [10-15], which requires higher skills and animals had to tolerate surgery. Postoperative malnutrition of and stress to the animals have also been problematic with these procedures. Dog models are limited by prohibitive costs. Rabbit models are not ideal for in-depth studies since uncommon disease processes are encountered in this model. Rats can be raised easily, but their cough reflex is insensitive, so they are not appropriate for the study of refluxassociated respiratory symptoms $[15,16]$. Guinea pigs [16] are the most sensitive animals for respiratory disease, given that their lungs are highly responsive. Both early and late asthmatic responses, for instance, can be elicited in these animals. In the present study, a model for reflux esophagitis was established in guinea pigs via simple perfusion of the middle and lower lumen of the esophagus with $\mathrm{HCl}-\mathrm{P}$ for 14 days. In these animals, the histopathology of the acid-treated lower esophagus was consistent with typical histological findings associated with reflux esophagitis [15].
Our data indicate that $\mathrm{HCl}$ perfusion induced chronic inflammation in the airways and lungs of guinea pigs similar to those of patients with reflux-associated respiratory symptoms [17], indicating that our animal model is well suited for studying reflux-associated respiratory symptoms. Airway inflammation is also triggered by factors that may also contribute to airway hyperresponsiveness.

In summary, external esophageal perfusion in the guinea pig is a feasible model of reflux-associated respiratory symptoms. The surgery performed in this model is less invasive than previous procedures, and postoperative stress to the guinea pigs is minimal. The external esophageal perfusion model successfully induced the typical histological and cellular changes associated with reflux esophagitis and inflammation of the airways and lung.

In conclusion, this study represents the first description of pulmonary inflammatory responses induced by GERD. Our findings suggest that repetitive acid perfusion of the esophagus can initiate an inflammatory response in the airways and lung. This finding supports an association between GERD and pulmonary diseases, such as asthma.

\section{References}

1 Vakil N, van Zanten SV, Kahrilas P, Dent J, Jones R, Globla Consensus Group: The Montreal definition and classification of gastroesophageal reflux disease (GERD) - a global evidence-based consensus. Am J Gastroenterol 2006;101:1900-1920.

-2 Shaheen N, Ransohoff DF: Gastroesophageal reflux, Barrett esophagus, and esophageal cancer: scientific review. JAMA 2002;287: 1972-1981

-3 Hungin AP, Raghunath A, Wiklund I: Beyond heartburn: a review of the spectrum of reflux-induced disease. Fam Pract 2005;22: 591-603.

-4 Havemann BD, Henderson CA, El-Serag HB: The association between gastro-oesophageal reflux disease and asthma: a systematic review. Gut 2007;56:1654-1664

5 Daoui S, D’Agostino B, Gallelli L, Alt XE, Rossi F, Advenier C: Tachykinins and airway microvascular leakage induced by $\mathrm{HCl}$ intraoesophageal instillation. Eur Respir J 2002; 20:268-273

-6 Hamamoto J, Kohrogi H, Kawano O, Iwaqoe H, Fujii K, Hirata N, Ando M: Esophageal stimulation by hydrochloric acid causes neurogenic inflammation in the airways in guinea pigs. J Appl Physiol 1997;82:738-745.
Adams J, Heints P, Gross N, Andersen P, Everts E, Wax M, Cohen J: Acid/pepsin promotion of carcinogenesis in the hamster cheek pouch. Arch Otolaryngol Head Neck Surg 2000;126:405-409.

8 Zijlstra FK, Hynna-Liepert TT, Dinda PK, Beck IT, Paterson WG: Microvascular permeability increases early in the course of acid-induced esophageal injury. Gastroenterology 1991;101:295-302.

-9 Underwood S, Foster M, Raeburn D, Bottoms S, Karlsson JA: Time-course of antigeninduced airway inflammation in the guinea-pig and its relationship to airway hyperresponsiveness. Eur Respir J 1995,8: 2104-2113.

10 Xu X, LoCicero J 3rd, Macri E, Loda M, Ellis FH Jr: Barrett's esophagus and associated adenocarcinoma in a mouse surgical model. J Surg Res 2000;88:120-124.

11 Chen X, Yang G, Ding WY, Bondoc F, Curtis SK, Yang CS: An esophagogastroduodenal anastomosis model for esophageal adenocarcinogenesis in rats and enhancement by iron overload. Carcinogenesis 1999;20:18011808 .
12 Chen X, Ding YW, Yang G, Bondoc F, Lee $M J$, Yang CS: Oxidative damage in an esophageal adenocarcinoma model with rats. Carcinogenesis 2000;21:257-263.

-13 Goldstein SR, Yang GY, Curtis SK, Reuhl KR, Liu BC, Mirvish SS, Newmark HL, Yang CS: Development of esophageal metaplasia and adenocarcinoma in a rat surgical model without the use of a carcinogen. Carcinogenesis 1997;18:2265-2270.

14 Goldstein SR, Yang GY, Chen X, Curtis SK, Yang CS: Studies of iron deposits, inducible nitric oxide synthase and nitrotyrosine in a rat model for esophageal adenocarcinoma. Carcinogenesis 1998;19:1445-1449.

15 Elton C, Uppal R, Moore D, Goldspink G, Winslet M: Partial cardiomyectomy - an animal model of gastro-oesophageal reflux. Int J Surg Investig 1999;1:81-85.

16 Tatar M, Pecova R, Karcolova D: Sensitivity of the cough reflex in awake guinea pigs, rats and rabbits (in Slovak). Bratisl Lek Listy 1997;98:539-543.

$\checkmark 17$ Carpagnano GE, Resta O, Ventura MT, Amoruso AC, Di Gioia G, Giliberti T, Refolo L, Foschino-Barbaro MP: Airway inflammation in subjects with gastro-oesophageal reflux and gastro-oesophageal reflux-related asthma. J Intern Med 2006;259:323-331. 